\title{
Kovács Olivér: Stabilitás és dinamizmus. Az innovatív fiskális politika alapjai
}

\author{
Alinea Kiadó, Budapest, 2015, 310 o.
}

A kötethez írott előszavában Mustó István azzal a kérdéssel szembesíti az olvasót, vajon tekinthetö-e értéknek a kiegyensúlyozott költségvetési politika. A válasz bár nem egyértelmü, mégis tény, hogy hajlamosak vagyunk a hiánymutatókra úgy tekinteni, mint amelyek képesek átfogó és meggyőző pillanatfelvételt adni egy gazdaság állapotáról, illetve a mindenkori kormányzat gazdaságpolitikájának fenntarthatóságáról. Hovatovább a hiány hiányát gyakorta azonosítjuk magával a fenntarthatósággal. Holott utóbbi eredetileg egy más kontextusban, a fejlődés kritériumaként jelent meg a tudományos diskurzusban és a közpolitika-formálásban. Kovács Olivér ehhez az eredeti jelentéshez nyúl vissza akkor, amikor megfogalmazza nemleges válaszát Mustó István kérdésére. Nála ugyanis a kiegyensúlyozott költségvetési politika önmagában nem érték. Hogy nézőpontja helyességét igazolja, kiragadja a költségvetési politikát a szokványos elemzési keretből és azt egy igencsak „nagy képbe” helyezi, ahol ember, természet és technológia interakciói határozzák meg a végső kimeneteket.

Ezért a kötet egyik fontos tétele, hogy a költségvetési konszolidációk sikerességének feltárásában sem elegendő a szüken vett költségvetési politika területén maradni. A szó legjobb értelmében rendszerszemléletben írott kötet szerzőjét az motiválta, hogy meghaladja az irodalomból jól ismert stabilizáció vagy növekedés dilemmát. Ahhoz azonban, hogy túllépjen e jól ismert választáson, a szűken vett közpénzügyi irodalom határain túlra tekint. Mindezt oly tágra nyitott keretek között teszi, hogy a kötetben sarokpontként hivatkozott fenntarthatóság nála egyszerre gazdasági, természeti és társadalmi jelenség. Magától értetődő ezért, hogy a kutatási cél interdiszciplináris megoldásokat kíván. Annál kevésbé magától értetődő, hogy a siker kovácsa a szerző meglátása szerint maga az állam (szükebben: a kormányzat) is lehet, amennyiben képes a költségvetési reformokat oly módon szervezni, hogy azok egy nagyobb léptékü modernizáció, transzformáció előmozdítóivá váljanak. Ilyen értelemben az állam látható keze legalább olyan fontos, mint a piaci láthatatlan kéz. A kormány látható keze ugyanis az, ami a szerző szerint képes lehet egy olyan konszolidáció feltételeinek megteremtésére, amely hatásaiban egyszerre stabilizáló és dinamizáló. 
A viszonylag rövid bevezetőben a szerző a kutatás motivációit és módszerét definiálja. Hivatkozási pontként vezeti be a Hicks-Kaldor-féle hatékonysági kritériumot, amely e kötetben konkrétan az olyan konszolidációkhoz kapcsolódik, amelyek növekedési többleteket generálnak, azaz elvi lehetőséget biztosítanak a vesztesek kompenzálására. A stabilitás vagy növekedés dilemma meghaladásának igényét és lehetséges előfordulásait így egy nem szokványos prizmán át szemléli és szemlélteti, azonban nem egyszerüen az előbbi definíció szerinti sikeres konszolidációk feltételeit keresi, ennél jóval többre vállalkozik. Azt keresi, hogy „mi lehetne az a potenciális elméleti keret, amely segítő támasza az ilyen jellegü konszolidációk fölfejtésének, s amely a fiskális politika számára értelmező keretként is szolgálhat" (23. o. - kiemelés az eredetiben, B. I.).

A kötet 2. fejezete a szélesen értelmezett fenntarthatóságot járja körbe két nagyobb egységben. Előbb egy igen alapos és olvasmányos irodalomismertetést olvashatunk, amiböl kiderül, hogy a fejezet, illetve a teljes kötet vállalt célja, hogy a közgazdasági diskurzusba bekapcsolja azokat a határ- (vagy nem is annyira határ-) területeket, amelyeknek érdemi mondanivalójuk lehet a fenntarthatóságról. Úgy tünhet, mintha a szerző nagyon távolról közelítene voltaképpeni témájához, a sikeres konszolidációhoz, de ez így nem feltétlenül igaz. A transzformatív erejü konszolidáció sajátja ugyanis éppen az, hogy egyfelől a gazdasági szférán kívüli - a döntéshozókat korlátozó - feltételekre is épít, másfelől maga is hat arra a struktúrára, ami egy kiigazítás széles értelemben vett velejárója.

A fejezet másik nagy egységében a fenntarthatóság koncepcióját Európára vetítve tárgyalja a szerző. Elsőre ez a fajta szerkesztési elv zavarónak tünhet, mivel látszólag megbontja a könyv saját maga diktálta logikáját, miszerint a (nagyon) nagy egységtől jutunk el a kicsiig (fenntarthatóság - gazdasági fenntarthatóság költségvetési fenntarthatóság - költségvetési kiigazítás), ám később értelmet nyer, hiszen egyértelművé válik, hogy a szerzőnek elsősorban az európai konszolidációkról van véleménye, $s$ a fenntarthatóság perspektívájából több „fajsúlyos kihívást" is azonosít. A termelékenységi rés növekedése, illetve az európai potenciális növekedési ütem zsugorodása kapcsán például kifejti, hogy a $\mathrm{K}+\mathrm{F}$-rés mérséklése nélkül Európa elveszíti esélyét a lépéstartásra (40. o.). A társadalmi kihívások sorában a demográfiai változásokat tartja leginkább fontosnak, aminek során az európai szociális modell a társadalom idősödése miatt kivérezhet. Egyebek mellett (sokkal) intenzívebb munkaerő-mobilitást sürget (41. o.). Némi ellentmondást sugall ugyanakkor, hogy míg a kötet bevezető fejezetében a fenntartható fejlődést a „folytonos szociális jóllét” biztosíthatóságával azonosítja a szerző (26. o.), addig a 2.2. alfejezetben az európai szociális modell fenntarthatatlanságát egyebek mellett éppen az Egyesült Államok, illetve Ázsia országaihoz képest „nagyvonalúnak számító jóléti juttatásokra, a méltányos munkaórákra, a hosszabb vakációk és korai nyugdíjazás (...) lehetőségére” (41. o.) vezeti vissza.

A harmadik fejezet a fenntarthatóság egy szűkített definícióját, a költségvetési fenntarthatóságot veszi górcső alá. Hasonlóan más szerzőkhöz, első körben Kovács Olivér is az állam költségvetési korlátját hívja segítségül a definíció tartalmának tisztázásához. Föként az adósságállomány finanszírozhatóságának mikéntjét, valamint 
a fizetési kötelezettség, pontosabban a kamatteher gazdasági növekedésre gyakorolt hatását értékeli. Sorra veszi az ismert mutatókat, majd egy merész fordulattal a költségvetési fenntarthatóság költség-haszon elemzését kínálja. A hasznok között megemlítve az intergenerációs tudatosság erősödését, az intézményi környezet minőségének javulását, vagy a költségvetési mozgástér fokozódását (58. o.). A költségek között szerepelnek - egyebek mellett - mindazon erőfeszítések, amelyeket egy kormányzat azért tesz, hogy biztosítsa közpénzügyei fenntarthatóságát (61. o.). Megkülönbözteti a közös akaratból (vagy legalábbis jóváhagyással) végrehajtott kiigazítások költségeit a konszenzus hiányában tett kiigazító lépések (jóval nagyobb) költségeitől. E különbségtétel nyit utat az első fejezetben beígért szélesebb kontextus beemelésére. A közösségi választások elméletének nyomvonalán haladva, a szerző előbb az emberi természetről (a rövid táv preferálása) értekezik, majd a politikai intézmények és intézkedések összefüggéseiről. Innen már csak egy lépés annak felismerése, hogy „,[k]özgazdasági szempontból a kiigazítás egyfajta tapasztalati jószág (...) amelyet hatásai révén lehet megítélni. Viszont helytállónak tünik az a vélekedés, hogy a kiigazítás a bizalmi jószágok közé is besorolható.” (63. o.)

A költségek azonban a szerző szerint nem csak a fenntartható pályára való (viszsza)kerülés során jelentkeznek. A fenntarthatóvá tett költségvetési politika bizonyos fokú rugalmasságot igényel, „hiszen az öregedő társadalom, de a természeti erőforrások kimerülése is megnövekedett fiskális adaptációs készséget követel meg" (67. o.). Ennek során döntést kell hozni arról, hogy milyen konkrét politikai-intézményi környezetben várható a jobb költségvetési teljesítmény, hogy miként keveredjék a szabályalapú gazdaságpolitika a diszkrecionálissal (68. o.).

A költségvetési konszolidációk elméleti és empirikus tanulságai címü fejezet arra a kérdésre keresi a választ, hogy mitől lehet egy kiigazítás sikeres. A fejezet a témakör nemzetközi és hazai irodalom kritikai összefoglalója; azt a célt szolgálja, hogy bemutassa: nem létezik sem egységes recept a sikerre, sem pedig egységes elemzési keret, amelyben a sikerességet vizsgálni és értelmezni lehetne. A 4. fejezet gyakorlatilag az úgynevezett nem keynesi hatások, azaz az expanziós, növekedést generáló költségvetési konszolidációk lehetőségének értékelését adja a legfontosabb szerzők alapján. A szerző célja itt az volt, hogy az irodalom alapján azonosítson néhány olyan kritériumot, amelyek megléte esetén remélhető a nem pozitív költségvetési multiplikátorhatás elérése. A recenzens maga is sokat foglalkozott e témával (lásd különösen Benczes [2008]), ezért itt csak két olyan megjegyzést teszünk, ami árnyal(hat)ja a fejezet következtetéseit.

A kevésbé lényeges észrevétel az, hogy érdemes markánsan különbséget tenni a keresleti és a kínálati oldali magyarázatok között, mivel mind hatásmechanizmusuk, mind pedig a megfigyelt következmények és ekképpen a sikeresség feltételei nagyon is eltérnek e két rezsimben. (Tény, hogy erre helyenként utal maga a szerző is, de nem meggyőző részletességgel.) Ám ami ennél sokkal lényegesebb, az az, hogy a nem keynesi hatások definíciószerüen a költségvetési kiigazítások rövid távú növekedési hatásait vizsgálják, jellemzően említésre sem kerül az a fajta hosszú táv, ami e kötet központi témája. A kiigazítás hatásait maximum hároméves távlatokban kutatják a kötetben is hivatkozott szerzők. Mindez nem véletlen, hiszen a standard 
megközelítés szerint a költségvetési politika a kiadások és/vagy a bevételek változtatása által meghatározóan rövid távon képes hatást gyakorolni az aggregált keresletre - már ha erre egyáltalán képes.

Politikai gazdaságtani megközelítésben is a rövid táv a releváns a gazdasági döntésekben (legalábbis demokratikus választási rendszerekben). Éppen ezért volt a válság előtti időkben olyannyira népszerü a növekedést (más megközelítésben: elosztható többleteket) generáló költségvetési konszolidációk feltételeinek rendszerbe foglalása, hiszen egy politikusnak mérlegelnie kell, hogy adott konszolidációs lépések mekkora költséggel és mekkora haszonnal járnak a döntéshozó számára releváns időhorizonton, azaz még a következő választások elött.

A nem keynesi hatásokat vizsgáló irodalom ugyan nem érzéketlen az olyan strukturális változásokra, amelyek valóban hosszú távon is képesek fenntarthatóvá tenni egy-egy kiigazítást, de nem ez az elsődleges szempont a vizsgálódásban. A leginkább Alesina és munkatársai által elvégzett kutatómunka is azt igazolja (Alesina-Perotti [1995] és Alesina és szerzőtársai [1998]), hogy a nemzetközi környezet, vagy éppen a valutarezsim mind meghatározók a sikerben; ám a kutatások középpontjában inkább a kiigazítás nagyságának és legfőképpen összetételének kérdése áll. Minden cinizmus nélkül állítható ezért, hogy a nem keynesi hatások érvényesülése esetén a valóban izgalmas kérdés az alkalmazott eszközök politikai bevethetősége és eladhatósága, nem pedig azok hosszú távú fenntarthatósága - utóbbi ugyanis már egy szerencsés következménye, de nem feltétele a sikernek. Így amikor Kovács Olivér azt írja, hogy „[e]gy olyan általános implikáció adódik, hogy a nem keynesi hatások léte elválaszthatatlanul összefügg a gazdaság növekedési képességével" (91. o. - kiemelés az eredetiben, $B . I$.), akkor ugyan nyilvánvalóan igaza van, de a fentiek tükrében túlzó is e kritikának szánt gondolat, hiszen olyasvalamit kér számon a hivatkozott kutatási programon, ami annak vállaltan nem (volt) része.

Mindez természetesen nem érvényteleníti a szerző azon meglátását (amit egyébként egy szabatosan megfogalmazott hipotézis is rögzít a kötet 91. oldalán), hogy egy gazdaság növekedési képessége, amelynek mind belső, mind pedig külső forrásai is vannak, nagymértékben közrejátszik abban, hogy sikeres lesz-e egy adott kiigazítás. Sőt kifejezetten örvendetes, hogy a szerző megpróbált egyfajta szintézist létesíteni, amely által a következő, 5. fejezetben eljutott a transzformatív erejü költségvetési konszolidáció gondolatához. Transzformáción értve azt a technológiai-gazdasági paradigmaváltást, ami a kötetben új gazdaságnak nevezett irányba (az információs és kommunikációs technológiára épülő gazdaságba) tereli az érintett országot. Ahogy korábban már utalás történt rá, e folyamatban nemcsak a smithi láthatatlan kéz, hanem az állam látható keze is kiemelt szerepet kap. A kötet újszerüsége talán éppen az lehet, hogy a költségvetési kiigazítás (hosszú távú!) sikerességét hozzáköti a technológiai-gazdasági paradigmaváltáshoz. Az állam tehát ebben a felfogásban fejlesztő - olyan fejlesztő, amely a költségvetési konszolidáció megtervezésekor hatványozottan figyel arra, hogy a kiadások és bevételek szerkezete úgy változzon az adott országban, hogy azzal a gazdaság növekedési képességét is emelje. Konkrétabban: tudatosan támogatja a $\mathrm{K}+\mathrm{F}$-tevékenységet, és tereli a szereplőket az új gazdaság irányába. A kiigazítások irodalmában ma már klasszikus sikertörténetnek számító Dániát 
(1983-1984) és Írországot (1987-1989) ilyen sikeres paradigmaváltáson átesett országoknak láttatja a szerző, ahol az állam a konszolidáció során tudatosan vállalta a technológiai transzformáció elősegítését.

Az 5. fejezet egyszersmind további öt hipotézist is megfogalmaz, amelyek részletes ismertetésétől itt most eltekintünk. Két szempontra azonban célszerű rámutatni. Először is Kovács kiáll amellett, hogy „[p]olitikai konszenzusra van szükség (...) a fiskális konszolidáció során is nélkülözhetetlennek tủnik a fiskális fenntarthatóság és a gazdaság átalakítása melletti belső elköteleződés" (130. o. - kiemelés az eredetiben, $B$. I.). Mindez rendjén is volna, de az igazán izgalmas kérdés, amelyre hipotézis formájában megelölegezett választ várnánk, az volna, hogy miként érhető el a joggal igényelt konszenzus, miként teremthető meg az elköteleződés egy olyan közegben, amelyben a politikai racionalitás nemritkán felülírja a gazdasági racionalitást (itt most utóbbin a technológiai-gazdasági paradigmaváltás szükségességét értve). Másodszor, talán éppen a 6. hipotézis (131. o.) teszi leginkább egyértelművé azt a problémát, ami a kötet egészén végigvonul. A fenntarthatóság vajon a siker előfeltétele vagy maga a siker, amiért a kormányzatnak munkálkodnia kell egyéb eszközeivel? Ez fontos kérdés, hiszen mint a szerző írja, „, [a]z állam hosszú távú finanszírozhatósága nélkül vészesen megfogyatkozik az a fiskális mozgástér, amely az új paradigmában történő későbbi növekedés belső tartalékainak építhetőségére lenne fordítható" (131. o.).

A fejezet következő nagy egysége két esettanulmányt közöl. Előbb Finnország példája szemlélteti a sikeres transzformatív erejü konszolidációt, majd Portugália hivatott szemléltetni a kudarcot. A finn eset hálás téma, hiszen minden benne van, ami egy sikertörténethez kell: innováció, angyali körök, társadalmi konszenzus stb. A portugál példa pedig mintha a finn eset antitézise volna: instabilitás, lassú menetelés, konzerválás - hirdeti az 5.3.2. alfejezet címe (165. o.). Az esettanulmányok jól eltaláltak, logikusan felépítettek, és tökéletesen beteljesítik azt a célt, amit nekik szánt szerzőjük: igazolják, hogy a költségvetési konszolidáció sikere nagymértékben függ attól a tágan értelmezett kontextustól, amelyben végrehajtják az egyes intézkedéseket.

A szerző a tanulságok levonása helyett egy újabb koncepció, az innovatív költségvetési politika felvázolásával zárja a kötetet. Az innovatív jelentése itt többszintü. Jelenti azt, hogy a költségvetési politika intelligens és holisztikus és egyben fenntarthatóságra törekszik - de jelenti azt is, hogy maga is innovál, fejleszt és fejlesztésre ösztönöz; üdvözli a kezdeményezőkészséget és teret hagy a diszkrecionális intézkedéseknek. Mint azonban az esettanulmányok is bizonyították, nem léteznek egységes receptek arra, hogy pontosan mitöl lesz sikeres egy állam. A szerző szerint a döntő tényező az, hogy mennyiben képesek a döntéshozók kiaknázni az adott ország növekedési képességét, illetve mennyiben képesek felismerni a változás és változtatás szükségességét, valamint ahhoz rendelni a megfelelö eszközöket és forrásokat. Talán ebben a fejezetben mondja ki leghatározottabban, hogy nincs igazán értelme deficitvagy adósságállomány-célokra lőni, mert azok a stabilitás és fegyelem sérülékeny látszatán kívül egyebet nem adnak. Minden ország más, és ekképpen minden országnak magának kell megtalálnia azt az utat, ami fejlődésre vezet. Ebben a költségvetési politikának - a standard, tankönyvi állásponttal ellentétben - nagyon nagy szerepe van (vagy legalábbis azt tulajdonít neki a szerző). 
Kovács Olivér kiváló munkája olyan költségvetési konszolidációért száll síkra, amely nem egyszerüen stabilizál, de a növekedést is támogatja. Ahogy ő írja, transzformatív erejü, vagyis képes arra, hogy a gazdaság és társadalom mélyebb rétegeit is áthassa, azok struktúráját átformálja. Az olvasó a sorok között azt az egyértelmü igényt is felleli, amely a nem túl távoli jövőben olyan akadémiai kutatásokat vizionál, amelyekben a figyelem nem egyszerüen a konszolidáció tényére (ha tetszik: a deficit lefaragásának mértékére), hanem annak széles értelemben vett feltételrendszerére, valamint közvetlen és közvetett hatásaira esik. A kiigazítás a szerző számára ugyanis nem cél, sokkal inkább eszköz. Eszköz, amely a gazdasági fejlődést és átalakulást szolgálja. Szemléletét egyfelől a klímaváltozások, az idősödő társadalom, valamint a technológiai paradigmaváltások gazdasági és társadalmi viszonyokat átrendező és ezen globális változásoknak az interdiszciplináris kutatásokban is megjelenő lenyomatai motiválták. Másfelől neki is - ahogy egy teljes felnövő közgazdász-generációnak meghatározó élménye a jelenkori gazdasági és pénzügyi válság és a válság jelentette bizonytalanság. Ez a kötet maga is az új generáció egy jeles alkotójának tollából való, de nem csak az új generáció tagjainak íródott.

\section{Hivatkozások}

Alesina, A.-Perotti, R. [1995]: The political economy of budget deficits. International Monetary Fund, Staff Papers, 42. 1-31. o. http://dx.doi.org/10.2307/3867338.

Alesina, A.-Perotti, R.-Tavares, J.-Obstfeld, M.-Eichengreen, B. [1998]: The political economy of fiscal adjustments. Brookings Papers on Economic Activity, 1. 197-266. o. http://dx.doi.org/10.2307/2534672.

Benczes István [2008]: Trimming the sails. The comparative political economy of expansionary fiscal consolidations. CEU Press, Budapest-New York.

Benczes István 